\title{
Alih Teknologi Peningkatan Nilai Gizi Opak Ikan Bagi Pelaku Usaha Produk Makanan Berbasis Ikan Di Desa Kiyab Jaya Kecamatan Bandar Sikijang Kabupaten Pelalawan
}

\author{
DWIKA LODIA PUTRI ${ }^{1}$; ADI RAHMAT ${ }^{2}$; AZNURIYANDI $^{3}$ \\ Universitas Lancang Kuning \\ Jln. Yos Sudarso KM 08 Rumbai Telp. (0761) 52581 \\ E-mail : lodiaputri_62@yahoo.com
}

\begin{abstract}
In Kiyab Jaya village Bandar Sikijang subdistrict Pelawawan district there are many home based business people who process fish based dry food. The food processing activities are opaque crackers, salmon and salted fish, which in the processing of these products requires a drying process. Currently the product drying process is very dependent on the weather or the heat of the sun, so that if the weather conditions are rainy or cloudy the product cannot be dried so that the product experiences decay and ultimately harms the business. Through technological innovation in drying fish based food products and other foodstuffs with different heat efficient dryers, it is expected that the products produced can be improved. The development of these small businesses will have an impact on the absorption of local labor and increasing family economic income. Therefore the application of appropriate drying technology with different heat sources is very necessary. The objectives of this service activity are: a) to introduce and apply the use of appropriate dryers with different heat sources to support the business of cassava and fish based processed products so that they can be used as regional superior products and their main livelihoods, in the context of business development and increasing family income, and b) as input for the government in the framework of planning the development of community micro enterprises in the area of potential food based businesses (yams and fish) and people's economy.
\end{abstract}

Keywords: Appropriate dryers, sweet potato and fish based products

Di desa Kiyab Jaya Kecamatan Bandar Sikijang Kabupaten Pelalawan, banyak terdapat pelaku usaha industri rumah tangga mengolah makanan kering berbasis ubi dan ikan. Kegiatan pengolahan kerupuk opak, mendominasi usaha rumah tangga tersebut, di mana dalam pengolahan produk tersebut membutuhkan proses pengeringan.

Saat ini proses pengeringan produk tersebut sangat tergantung pada cuaca atau panas sinar matahari, sehingga bila kondisi cuaca hujan atau mendung produk tidak dapat dikeringkan yang mengakibatkan pembusukan pada produk dan akhirnya merugikan pelaku usaha. Dengan demikian permasalahan utama yang dihadapi oleh kelompok usaha tersebut adalah masalah teknologi untuk pengeringan produk khususnya produk makanan berbasis ubi dan ikan. Hal ini disebabkan karena kelompok usaha pengolahan mengalami kesulitan dalam proses pengeringan, sehingga apabila masih mengandalkan proses pengeringan dengan sinar matahari, maka sulit diprediksi produk bisa kering dan akhirnya produk menjadi busuk.

Dewasa ini, dari berbagai hasil Kegiatan yang telah dilakukan diperoleh informasi bahwa untuk mengatasi permasalahan di atas diperlukan sentuhan teknologi pascapanen untuk menyelamatkan hasil produksi. Oleh karena itu pengembangan teknologi dalam bidang pengolahan hasil-hasil perikanan adalah suatu langkah yang paling logik dalam usaha memajukan aktivitasaktivitas pengolahan hasil perikanan.

Sebagaimana kita ketahui bahwa permintaan produk kerupuk opak ikan,dan produk makanan kering lainnya menunjukkan kecendrungan meningkat, oleh karena itu diperlukan teknologi 
pengeringan tepat guna untuk memanfaatkan potensi ubi dan ikan guna meningkatkan nilai tambah produk dan sekaligus meningkatkan sumber pendapatan keluarga pelaku usaha.

Dengan demikian apabila industri pengolahan ubi dan ikan ini mendapat bimbingan terutama dalam pengembangan mutu produk yang dihasilkan, diyakini produksinya dapat meningkat. Disamping mutu produk yang masih rendah, finansial untuk menunjang peningkatan produksi juga terbatas. Upaya untuk mengatasi permasalahan tersebut sangat diperlukan pembinaan manajemen usaha agar pendapatan pelaku usaha pengolahan ubi dan ikan dapat meningkat.

$$
\text { Melalui inovasi teknologi }
$$

pengeringan produk makanan berbasis ubi dan ikan serta bahan pangan lainnya dengan alat pengering tepat guna sumber panas berbeda, diharapkan produk yang dihasilkan dapat ditingkatkan mutunya. Berkembangnya usaha-usaha kecil ini akan berdampak terhadap penyerapan tenaga kerja setempat dan peningkatan pendapatan ekonomi keluarga. Maka dari itu aplikasi teknologi pengering tepat guna dengan sumber panas berbeda sangat diperlukan.

\section{METODE}

Metode yang akan dilakukan oleh tim selama kegiatan pengabdian bagi masyarakat dengan Mitra Kelompok Usaha di Desa Kiyab Jaya Kecamatan Bandar Sikijang Kabupaten Pelalawan.

Metode Ceramah, dengan cara melakukan motivasi dengan menjelaskan langsung kepada mitra dengan tujuan untuk membangkitkan gairah jiwa bisnis/kewirausahaan.

Metode Praktek, dengan cara melakukan praktek secara langsung sesuai dengan materi yang akan disampaikan kepada mitra. Melalui kegiatan praktek langsung diharapkan mitra mendapatkan pengetahuan tentang cara mengolah bahan ubi dan ikan dalam meningkatkan alih teknologi peningkatkan gizi opak ikan.

\section{HASIL}

Pelaksanaan kegiatan pengabdian kepada masyarakat ini dilakukan di Desa Kiyab Jaya Kecamatan Bandar Sikijang Kabupaten Pelalawan dengan mitranya kelompok ibu rumah tangga sebagai kader PKK di Desa Kiyab Jaya.

Tim pelaksana terdiri dari 3 orang dengan peran masing-masing, Ketua Tim (Dwika Lodia Putri. SE., M.Ak) memberikan materi tentang kewirausahaan, praktek pelatihan pembuatan opak ikan, sedangkan anggota Tim (Dr. Adi Rachmat. SE., MM) memberikan materi pengembangan usaha dan Aznuriyandi. SE., M.Si, memberikan materi pemasaran dan alih teknologi.

Dari aktifitas budidaya ikan dikolam yang dilakukan oleh masyarakat desa Kiyab Jaya telah memacu dan memotivasi warga untuk melakukan usaha budidaya, yang kecenderungannya semakin meningkat jumlah lahan yang digunakan untuk usaha budidaya. Kondisi ini dapat menilai bahwa usaha budidaya ikan memiliki ekonomi usaha lebih baik.

Melihat potensi tersebut, maka kegiatan pemberdayaan masyarakat khusus kader PKK desa Kiyab Jaya sangat diperlukan, melalui alih teknologi pengolahan makanan berbasis ikan. Selain itu kegiatan tersebut untuk mengantisipasi bila terjadi panen raya yang umumnya menyebabkan harga ikan turun. Alih teknologi yang diberikan adalah alih teknologi pengolahan opak ikan.

Dalam masyarakat perdesaan umumnya masih sulit menerima sesuatu yang baru bagi mereka, namun demikian apabila program tersebut menyentuh kebutuhan mereka maka mereka sangat menerima program tersebut. Mengingat program kegiatan alih teknologi yang diberikan sangat menarik dan menurut mereka sangat dibutuhkan, maka respon masyarakat terhadap kegiatan ini sangat antusias, dari data yang diperoleh berdasarkan observasi dan wawancara bahwa respon peserta menyatakan sangat 
112 Alih Teknologi Peningkatan Nilai Gizi Opakikan Bagi Pelaku Usaha Produk Makanan Berbasis Ikan Di Desa Kiyab Jaya Kecamatan Bandar Sikijang Kabupaten Pelalawan (Dwika Lodia Putri, Adi Rahmat, Aznuriyandi)

bermanfaat sekitar $85 \%$ dan bermanfaat sekitar $15 \%$. Hal ini menunjukan bahwa masyarakat sasaran sangat antusias terhadap kegiatan alih teknologi ini, sehingga tingkat ketercapaian sasaran program sangat baik.

Dalam kegiatan pengabdian masyarakat ini dengan cara menyebarkan quisioner sebelum dan sesudah pelaksanaan pengabdian. Adapun untuk mengetahui pengetahuan dan pemahaman tentang alih teknologi peningkatan nilai gizi kerupuk opak ikan bagi pelaku usaha produk makanan berbasis ikan di Desa Kiyab Jaya Kecamatan Bandar Sikijang Kabupaten Pelalawan, dapat dilihat dari tabel 1 di bawah ini:

Tabel 1. Hasil Kuesioner Pengabdian Kepada Masyarakat

\begin{tabular}{|c|c|c|c|c|}
\hline \multirow[t]{2}{*}{ No } & \multirow{2}{*}{$\begin{array}{l}\text { Komponen } \\
\text { Kuesioner }\end{array}$} & \multicolumn{3}{|c|}{ Alternatif Jawaban } \\
\hline & & $\mathrm{T}$ & $\mathrm{N}$ & $\mathrm{Y}$ \\
\hline 1. & $\begin{array}{l}\text { Pengetahuan } \\
\text { mengenai } \\
\text { kewirausahaan dan } \\
\text { peluang usaha }\end{array}$ & $40 \%$ & - & $60 \%$ \\
\hline 2. & $\begin{array}{l}\text { Pengetahuan cara } \\
\text { pembuatan produk } \\
\text { keripik tempe sagu } \\
\text { hezel }\end{array}$ & $90 \%$ & - & $10 \%$ \\
\hline 3. & Praktek & - & - & $100 \%$ \\
\hline 4. & $\begin{array}{l}\text { Pengetahuan nara } \\
\text { sumber/pelaksana } \\
\text { kegiatan }\end{array}$ & - & - & $100 \%$ \\
\hline 5. & $\begin{array}{l}\text { Minat peserta untuk } \\
\text { mengembangkan } \\
\text { pembuatan produk } \\
\text { keripik tempe sagu } \\
\text { hezel }\end{array}$ & $10 \%$ & $15 \%$ & $75 \%$ \\
\hline
\end{tabular}

Keterangan: $\mathrm{T}=$ Tidak. $\mathrm{N}=$ Netral $\mathrm{Y}=\mathrm{Ya}$ Sumber: Data Olahan 2019

\section{PEMBAHASAN}

Proses kegiatan pengabdian dilakukan dengan cara demonstrasi dan ceramah, dimana ceramah dilakukan untuk menyampaikan informasi tentang kewirausahaan dan peluang usaha serta cara pembuatan opak ikan dan cara alih teknologi. Secara garis besar hasil kegiatan yang telah dicapai dalam pengabdian masyarakat ini adalah sebagai berikut:

1. Materi kegiatan, mengenai alih teknologi dan peluang usaha serta cara pembuatan kerupuk opak ikan pada umumnya dapat diterima dan dapat dipahami serta mendapat respon dari peserta yang ditandai dengan adanya pertanyaanpertanyaan yang muncul.

2. Berdasarkan sikap dan pertanyaan yang diajukan dapat diketahui bahwa materi pengabdian sangat membantu dalam peningkatan pengetahuan masyarakat.

3. Dari hasil pengabdian ini diharapkan nantinya akan ada tindak lanjutnya.

4. Berdasarkan evaluasi dapat diketahui bahwa pada umumnya peserta pengabdian telah memahami tentang alih teknologi peningkatan nilai gizi kerupuk opak ikan serta manfaatnya dalam meningkatkan perekonomian keluarga.

\section{SIMPULAN}

Setelah diberikan penyuluhan pelatihan alih teknologi peningkatan nilai gizi kerupuk opak ikan bagi pelaku usaha produk makanan berbasis ikan di Desa Kiyab Jaya Kecamatan Bandar Sikijang Kabupaten Pelalawan telah membuka peluang usaha rumahan guna meningkatkan pendapatan keluarga dan masyarakat setempat. Secara ekonomi pemanfaatan ikan dalam makanan jajanan sangat menguntungkan dan sekaligus mendukung program makan ikan (forikan) yang turut berkontribusi untuk peningkatan produksi ikan. Setelah kegiatan alih teknologi, terjadi respon masyarakat sasaran adalah $90 \%$ sangat membantu, dan $10 \%$ membantu.

Kami sebagai Tim menyarankan kepada para peserta agar mereka lebih menggali potensi keahlian yang dimiliki, termasuk memanfaatkan teknologi yang ada, bagi pelaku usaha produk makanan dengan keahlian yang dimiliki dibidang pembuatan hasil industri rumahan (pembuatan produk makanan berbasis ikan (opak ikan). Begitu juga dengan ahli teknologi yang diberikan dapat 
meningkatkan pendapatan keluarga.

\section{DAFTAR RUJUKAN}

Abdullah, C., D.S. Retroningrum. 2003. Deteksi Bakteri Patogen Streptococcus pyogenes dengan Tehnik Polymerase Chain Reaction (PCR). Jurnal Natur Indonesia. Pekanbaru. 5 hal.

Darmadji, P. 1997. Aktivitas Anti Bakteri Asap Cair yang Diproduksi Dan Bermacam-Macam Limbah Pertanian. Jurnal Agritech, 16 (4): 19-22.

Handoyo. 2011. Ekspor Ikan Sidat Merosot Tajam. http://mkbisnis.blogspot.com / 2011/11/kompascom-bisnis keuangan_27.html. 27 Februari 2012.

Leksono, T, Padil, and Aman, 2009. Application of Liquid Smoke Made of Oil Palm Shell on Fresh-Water Catfish (Pangasius hypopthalmus) Preservation. Procceding International Seminar : "From Ocean for Food Security, energy, and Sustainable Resources and Environment". Unair Surabaya, 18 Nopember 2009.

Martinez, O., J. Salmeron, M.D. Guillen, and C. Casas, 2007. Sensorial and Physicochemical Characteristics of Salmon (Salmo salar) Treated by Different Smoking Processes during Storage. Food Science and Technology International 2007; 13(6): 477-484. Los Angelos, London, New Delhi, and Singapore.

M, Freddy, 2014. Kajian Pengolahan ikan pora-pora (Mystacoleuseus padangesis) Asap Dengan Menggunakan Alat Pengering Sumber
Berbeda.Pekanbaru.Skripsi (tidak diterbitkan)

Pszczola, D.E.1995. Tour Highlights Production and Uses of SmokeBasedFlavors. Food Tech. 49 (1) : 70-74.

Sarihusada, 2012. Ikan Pora-Pora Penghasil Omega 3 dari Danau Toba.

http://nutrisiuntukbangsa.org/ikanpora-pora-penghasil-omega-3-daridanau-toba/. Diakses pada tanggal 21 Mei 2014.

SNI (Standar Nasional Indonesia) No. 012725. 2009. Ikan Asap. Badan Standarisasi Nasional.

Tapotubun A.M. dan Fien Soedirjo. 2008. Pengaruh Waktu Pengeringan Terhadap Kwalitas Dendeng Ikan Rucah Selma Penyimpanan. Seminar Nasional Tahunan V Hasil Penelitian Perikananan dan Kelautan, 26 Juli 2008.

Tranggono, Suhardi., Bambang Setiadji, Purnama Darmadji, Supryanto dan Sudarmanto. 1996. Identifikasi Asap Cair Dari Berbagai Jenis Kayu Dan Tempurung Kelapa. Journal Ilmu dan Teknologi Pangan $I(2): 15-24$.

Utomo, B.S.B., Febriani, R.A, Purwaningsih, S. dan Nurhayati, T. 2009. Pengaruh konsentrasi larutan asap cair terhadap mutu belut asap yang dihasilkan. Jurnal Pascapanen dan Bioteknologi 4 (1): 49-58.

http://karyatulisilmiah.com/ikan-baung$\underline{\text { mystus-nemurus/(diakses }}$ pada tanggal 2 desember 2014) 